\title{
History of the Gynecologic Clinic of the Hospital das Clínicas da Faculdade de Medicina da Universidade de São Paulo (Clinical Hospital of the University of São Paulo's Faculty of Medicine)
}

\author{
Laudelino Oliveira Ramos ${ }^{1}$, Edmund Chada Baracat ${ }^{2}$
}

rnaldo Augusto Vieira de Carvalho was born
in Campinas and at the age of 21 earned his degree in Medicine from the Rio de Janeiro Faculty of Medicine in 1888. Soon after, he came to São Paulo and was admitted to the medical staff at the Santa Casa de Misericórdia de São Paulo (São Paulo Holy House of Mercy). In this hospital, he reached the position of Director, which he held from 1894 to 1920, when he passed away.

On January 21, 1913 the São Paulo Faculty of Medicine and Surgery was founded and had Arnaldo Vieira de Carvalho as its leader due to his educational vision and brilliant career, setting the foundations for that which today is the Faculty of Medicine.

Gradually the Basic and Clinical Chairs were created, and the practical classes were taught at the Santa Casa de Misericórdia. Such classes continued to be taught there until the Clinical Hospital was built in 1945.

In 1918, the Arnaldo himself was nominated by the Congregation of the Faculty of Medicine as the director of the Chair of Gynecology and in his inaugural lecture he made an analogy to his career referring to Edmund Rostand's play in which the rooster believed to be responsible for the sunrise.

In the same year, the first steps towards constructing the building of the Faculty of Medicine were taken, with the Rockefeller Foundation's support . In the same year, the first graduates of the Faculty of Medicine received their degree and Arnaldo, to whom they paid special homage, said, among other things: "In addition to relieving the physical ailments of others, nowadays it is also the responsibility of the physician to restore the damaged society and the huge and complete task of sowing and improve the environment where both evolve".

On January 25, 1920, Arnold chaired the launching of the Faculty's cornerstone, which commenced the construction of the first block that would become the Legal Medical Institute, but that in the period from 1924 to 1931 housed the Library and the Chairs of Anatomy and Pathological Histology.

On June 5, 1920, with the death of Arnaldo, his first

1. Retired Associate Professor of the Gynecology Discipline of the Department of Obstetrics and Gynecology of the University of São Paulo's Faculty of Medicine (Departamento de Obstetrícia e Ginecologia da Faculdade de Medicina da Universidade de São Paulo - DOG/FMUSP.)

2. Full Professor of the Gynecology Discipline of the Department of Obstetrics and Gynecology of the University of São Paulo's Faculty of Medicine (Departamento de Obstetrícia e Ginecologia da Faculdade de Medicina da Universidade de São Paulo - DOG/FMUSP.) Mailing address: Clínica Ginecológica do HCFMUSP. (Gynecologic Clinic of the HCFMUSP) Av. Dr. Enéas de Carvalho Aguiar, 255. $10^{\circ}$ andar ICHC. (ICHC 10th floor) Cerqueira César, São Paulo, SP, Brasil. ZIP CODE: 05403-000. Email: secretariagin.ichc@hc.fm.usp.br 
assistant, Dr. José Ayres Netto, took over the Regency of the Chair of Gynecology. Then, the Congregation of the Faculty of Medicine opened a public selection for Professor of Gynecology scheduled for February 21, 1921. Jose Ayres Netto, Luciano Gualberto, Nicolau de Moraes de Barros and Nelson Libero Passos Cunha applied for it. The Examining Committee was composed of Professors A.C. Camargo, Alves de Lima, Oliveira Fausto, Silvio Maia and Professor Edmundo Xavier, who was the Director of the Faculty of Medicine then. After tests of evaluation of the memorial, a Didactic test and a Practical test, the Examining Committee nominated the winner of the tender, Professor Nicolau Moraes de Barros, which was endorsed by the Congregation of the Faculty of Medicine on March 23, 1921.

The new Professor could only begin his teaching activities in June 1921 as a result of the hindrances to the installation of his service at the Santa Casa. Doctors Erich Muller Carioba, Paulo de Godoy, Felix Queiroz, Celso de Godoy and José Bonifácio Medina, were nominated as his collaborating assistants, whereas the latter was nominated his first assistant, in1934.

On January 25, 1934, during the mandate of Governor Armando Salles de Oliveira, the University of São Paulo was created. Its installation took place on June 6, 1934, in the Congregation room of the Faculty of Medicine, with the first meeting of the University Council and inauguration of the first Dean. From then on, the São Paulo Faculty of Medicine and Surgery was named the University of São Paulo's Faculty of Medicine.

On August 18, 1944, Professor Nicolau de Moraes Barros retreated from the direction of the Chair of Gynecology and passed away in March 1959, at the age of 83. He was replaced by the Full Professor José Bonifacio Medina, which in May 1945 passed the tender to occupy the Chair of Gynecology, FMUSP. Professor Medina indicated Doctors José Gallucci, Arthur Wolff Netto and René Mendes de Oliveira as his official assistants.

In 1948, under the direction of Professor Medina, the Gynecology Clinic, which was installed at the Santa Casa, was transferred to the 10th floor of the Clinical Hospital, where it remains to this day.

During the administration of Professor Medina, the following Doctors entered the selection process for the position of Professor: José Gallucci, Paulo Gorga,
Domingos Lerario, Carlos Alberto Salvatore, Alvaro da Cunha Bastos, Hans W. Halbe, Bussamara Neme, Armando Bozzini, Domingos Andreucci, Octaviano Alves de Lima Filho and José Roberto de Freitas Azevedo.

With the Law of Directives and Bases of 1958, the Chairs were extinguished and the Departments composed of Subjects were created, which are the minimum units of a Faculty. Thus, the position of Full Professor of Obstetrics of the Department of Obstetrics and Gynecology was vacant due to the Professor Raul Briquet's death on September 4, 1953. In this way, José Bonifácio Medina, now Full Professor of Gynecology, takes the position of Head of thr FMUSP's DOG, nominated of the Congregation. During this period, the Gynecology Course was headed by Associate Professor José Gallucci.

Professor José Bonifácio Medina retired mandatorily on April 20, 1970 and passed away on May 31, 1993, at the age of 93. The Regency of the Gynecology Course was assumed by Associate Professor José Gallucci, but was interrupted six months later due to illness. The Headship of the Department of Obstetrics and Gynecology was then assumed by Professor Bussamara Neme who, advised by Professor Jose Gallucci, reshaped the structure of the Department, proposing and obtaining approval for the creation of two Full Professor positions - one for Obstetrics and other for Gynecology. In 1972, by tender of Tests and Titles, Professor Bussamara Neme was approved to occupy the position of Full Professor of the Obstetrics Course.

In 1973, the Congregation of the USP Faculty of Medicine opened a public selection of Tests and Titles for filling the position of Full Professor of the Gynecology course. The only candidate who applied for it and was approved was Professor Carlos Alberto Salvatore.

The new Full Professor of the Gynecology Course, with drive and great surgical skills, taught and encouraged his assistants and students, restructuring the Course and creating new sectors. The PSO (Pronto Socorro de Obstetrícia - Obstetrics Emergency) supported the obstetrics and gynecological emergencies, but in 1975 Professor Salvatore created the PSG (Pronto Socorro de Ginecologia - Gynecology Emergency). To this end, in addition to the physical space (an Emergency Room and beds in the ward), the hiring of eight new assistant duty physicians was necessary. This gynecological emergency 
sector, which was headed by Professor Sergio Peixoto, produced many papers, theses and books, resulting from the material and experience acquired there.

During the administration of Professor Carlos Alberto Salvatore, several assistants have applied for and passed the tender for the position of Professor: Aurélio Zecchi de Souza, Jorge Saad Souen, Domingos A. Petti, Laudelino de Oliveira Ramos, Sergio Peixoto, Angela Maggio da Fonseca, Vicente R. Bagnoli and Paulo Levy Schivartche. Two tenders for Associate Professor were also held. Professor Alvaro da Cunha Bastos applied for and was approved in the first one (1973); and the same happened with Professor Aurelio Zecchi de Souza in 1981.

In April 19, 1987 Professor Carlos Alberto Salvatore retired. Associate Professor Associado Aurélio Zecchi de Souza assumed the Regency of the Subject until the new Full Professor's inauguration. On June 18, 1988, the tender for the occupation of the position of Full Professor of the Gynecology Discipline of the FMUSP's DOG began. Its only candidate was Professor José Aristodemo Pinotti, who was approved with Honor and Laudat. He was born in São Paulo on December 20, 1934, graduated from FMUSP in 1958 and built his academic carreer at UNICAMP, where he reached the position of Full Professor Titular of Obstetrics and Gynecology, Director and Dean.

With experience in administration and teaching, Professor Pinotti reshaped and expanded the structure of the Gynecology Course, including the Gynecology Service of the HU, establishing links with the Perola Byington Hospital and recovering the Medical Research Laboratory.

The CH Complex (Complexo HC) includes several Institutes, a result from the idealization and accomplishment of Full Professors, such as the Orthopedics and Traumatoloy Institute, the Psychiatry Institute, the Nuclear Medicine Institute, the Tropical Medicine Institute, the Children's Institute, the Radiology Institute, the Heart Institute. A spirit of leadership and vision of the future led Professor Pinotti to idealize the Women's Institute. However, the original destination of the "Women's Institute" building was replaced by the ICESP (Instituto do Câncer do Estado de São Paulo - Institute of the State of São Paulo) which maintained the original plant.

Upon Professor José Aristodemi Pinotti’s leave on
December 20, 2004, Professor Domingos Auricchio Petti assumed the Regency of the Gynecology Discipline until the inauguration of the new Full Professor.

The candidates for the position of Full Professor of the Gynecology Discipline of the FMUSP's DOG were: Professor Edmund Chada Baracat - EPM, Professor Angela Maggio da Fonseca - FMUSP, Professor Vicente Renato Bagnoli - FMUSP, Professor Mauricio Simões Abrão FMUSP, Professor Nilson Roberto de Melo - FMUSP, Professor Alfredo Carlos Simões Dornellas de Barros FMUSP, Professor José Gonçalves Franco Junior - FMRP and Professor José Mendes Aldrighi - FCM - Santa Casa.

The public selection was scheduled for October 3 to 7, 2005, and the examining board was composed of Professors: Valentim Gentil - FMUSP, Milton de Arruda Martins - FMUSP, Mauri Piazza - UFPR, Gustavo Antonio de Souza - UNICAMP, Rui Ferriani - FMRP.

Professor Edmund Chada Baracat was chosen as the winner of this much disputed public selection. He began his activities as Full Professor of the Gynecology Discipline of the FMUSP's DOG in May, 2006.

Due to his performance in the areas of Endocrine Gynecology, Menopause and Translational Gynecology, he developed and stimulated both clinical and basic research in various sectors of the Discipline, as well as publications in nationally and internationally indexed Journals.

Changes were made to the infrastructure of the Gynecological Clinic, with the reform and modernization of the Ambulatory and the Governador Mario Covas Human Reproduction Center, which became part of the Gynecological Clinic of the FMUSP Clinical Hospital.

The LIM-58 (Medical Research Laboratory) has been fully restructured and started featuring modern equipment which has enabled for the conduction of morphological, immunohistochemical, biochemical and molecular research.

A major redesigning of the Organization chart of the Gynecological Clinic Division was also conducted with the creation of new sectors (Figure 1), to include the various practice areas of Gynecology. Similarly, there has been great emphasis on the teaching of Gynecology in its various spheres: graduation, residency and post-graduation. 


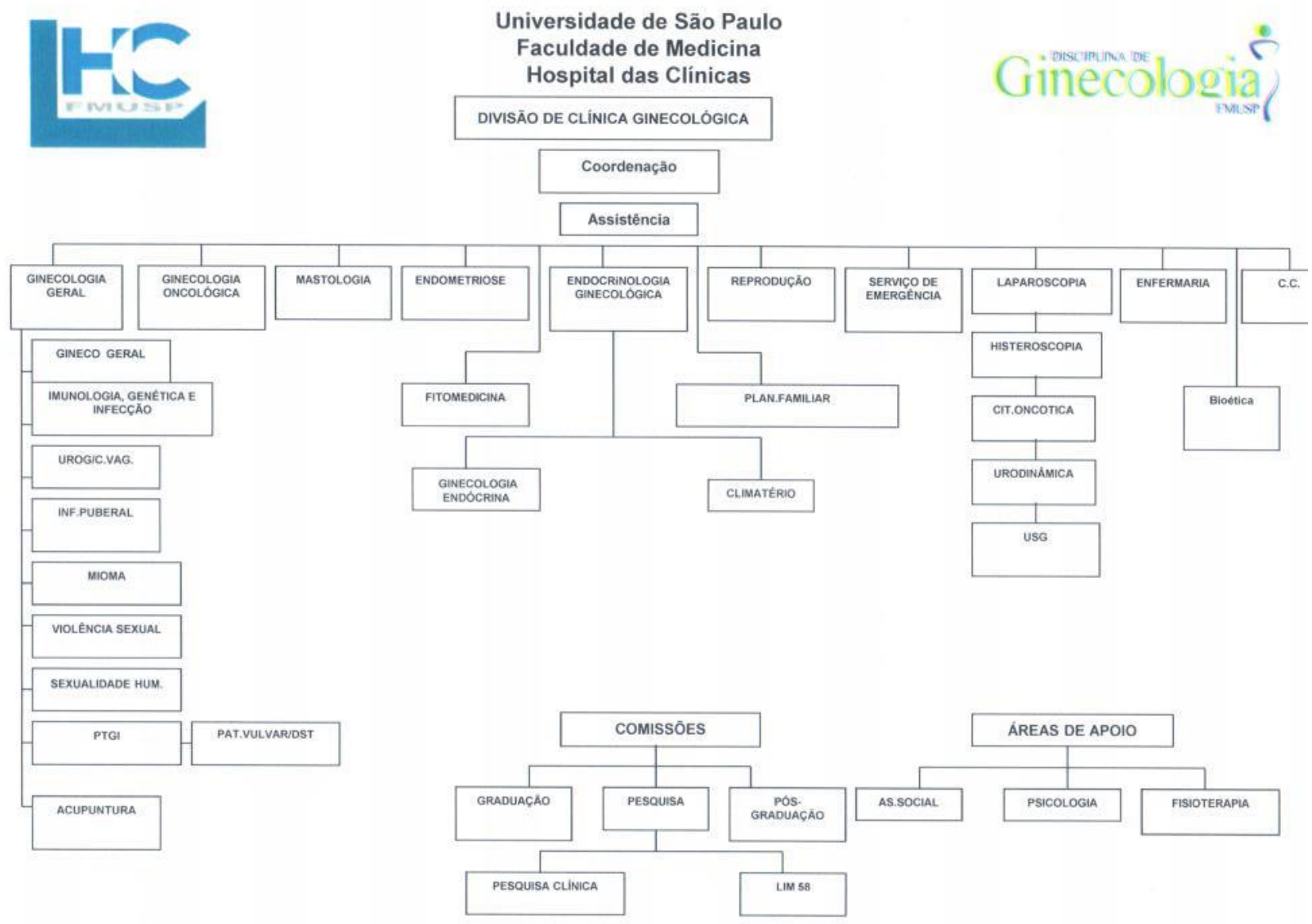

Figure 1. Organization Chart of the HCFMUSP's Gynecological Clinic

With funding obtained from external sources, it was also possible to modernize the range of equipment for diagnostic and therapeutic procedures (colposcopy, ultrasound, cistocopy, hysteroscopy, videolaparoscopy, etc.).

All these efforts were made so that the Gynecology Department and the Gynecology Clinic of the FMUSP Clinical Hospital can fulfill their mission to receive, diagnose and treat our population properly and in a less invasive manner.

During his administration, Doctors Nilo Bozzini, Paulo Cesar Serafini, Sergio Podgaec, Gustavo Maciel, José Roberto Filassi and Iara Moreno Linhares also applied for the position of Full Professor.
During this period, public selection were opened for the filling of six Doctor Professor - MS3 positions for the Gynecology Subject. The approved candidates were Mauricio Simões Abrão (2009), Isabel Cristina Esposito Sorpreso and Paulo Francisco Ramos Margarido (2010), Nilson Roberto de Melo, Paulo Cesar Serafini and José Maria Soares Júnior (2013).

\section{REFERENCE}

Trajetória da Faculdade de Medicina da Universidade de São Paulo: aspectos históricos da "Casa de Arnaldo". Departamentos da Faculdade de Medicina da Universidade de São Paulo: Memórias e Histórias. Departamento de Obstetrícia e Ginecologia. São Paulo; 2012. v.2, Cap. 11, p.173-6. 